\title{
JUURNAL_RU
}

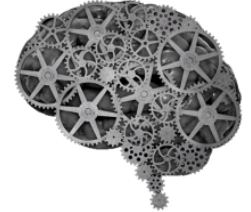

COMPANY GROUP "INTELLEKT"

\author{
Перинская Е.Д., Перинская И.В., Пичхидзе С.Я. \\ СГТУ им. Ю.А. Гагарина \\ Саратов, Россия
}

doi: 10.18411/lj2016-3-30

\section{Разработка методики ионно-лучевого модифицирования поверхности дентальных имплантатов с применением эффекта блистеринга}

Известно, что для повышения остеоинтеграции титановых внутрикостных имплантатов разработаны различные методы формирования биосовместимых покрытий, в основном на основе гидроксиапатита. Недостатками данных покрытий является то, что многокомпонентная, многослойная система покрытия и основы имеют различные коэффициенты термического расширения, что не способствует прочному закреплению (адгезии) слоев покрытия. Авторами [1-3] разработан способ повышения механических свойств внутрикостных титановых имплантатов с применением эффекта блистеринга.

Целью работы являлась разработка методики модификации поверхности внутрикостных дентальных имплантатов ионно-лучевой обработкой для повышения их биосовместимых и остеоинтеграционных характеристик.

Объектами исследования являлись внутрикостные титановые дентальные имплантаты.

Этапы методики ионно-лучевой модификации поверхности титана включали: 1) изготовление основы внутрикостного стоматологического имплантата из титана методами токарной и фрезерной обработки, механической полировки; 2) очистку поверхности титановой основы имплантата ультразвуковым способом ( $\mathrm{I}=1,2 \mathrm{BT} / \mathrm{cm}^{2}, \mathrm{~V}=22$ кГц, $\mathrm{t}=3$ мин); 3) химическое 
обезжиривание титановой основы имплантата в растворе тринатрийфосфата $\left(\mathrm{T}=70-90^{\circ} \mathrm{C}, \mathrm{t}=3-10\right.$ мин); 4) имплантацию ионов аргона $(\mathrm{E}=100-200$ кэВ, $\Phi=6 \cdot 10^{17}-6 \cdot 10^{18}$ ион/см $\left.{ }^{2}\right)$ в полированную поверхность титановой основы на установке ионного легирования типа «Везувий-5».

Результаты эксперимента и их обсуждение. При имплантации ионов аргона формируется пористая структура поверхности титановой основы имплантата с размером пор 100-250 мкм. Размеры пор находятся в пределах от d 100-250 мкм с плотностью $\mathrm{N} 10^{16}-10^{17} \mathrm{~cm}^{-3}$ и определяются энергией и дозой имплантации ионов аргона в титановую основу. Образование углеродной алмазоподобной беспористой пленки на сформированной пористой структуре поверхности титановой основы имплантата происходит при имплантации ионов аргона в вакуумной среде $\left(10^{-4}-10^{-5}\right.$ мм.рт.ст.) углекислого газа. При введении в костную ткань титанового имплантата со сформированной пористой структурой титановой основы с размером пор 100-250 мкм и сформированной на ее поверхности углеродной алмазоподобной беспористой пленкой наблюдается эффективное прорастание кости в поры поверхности (остеоинтеграция). Отростки клеток костной ткани, прорастающие в образованные поры поверхности имплантата имеют размеры 100-250 мкм, что обеспечивает прочное закрепление внутрикостного имплантата в организме.

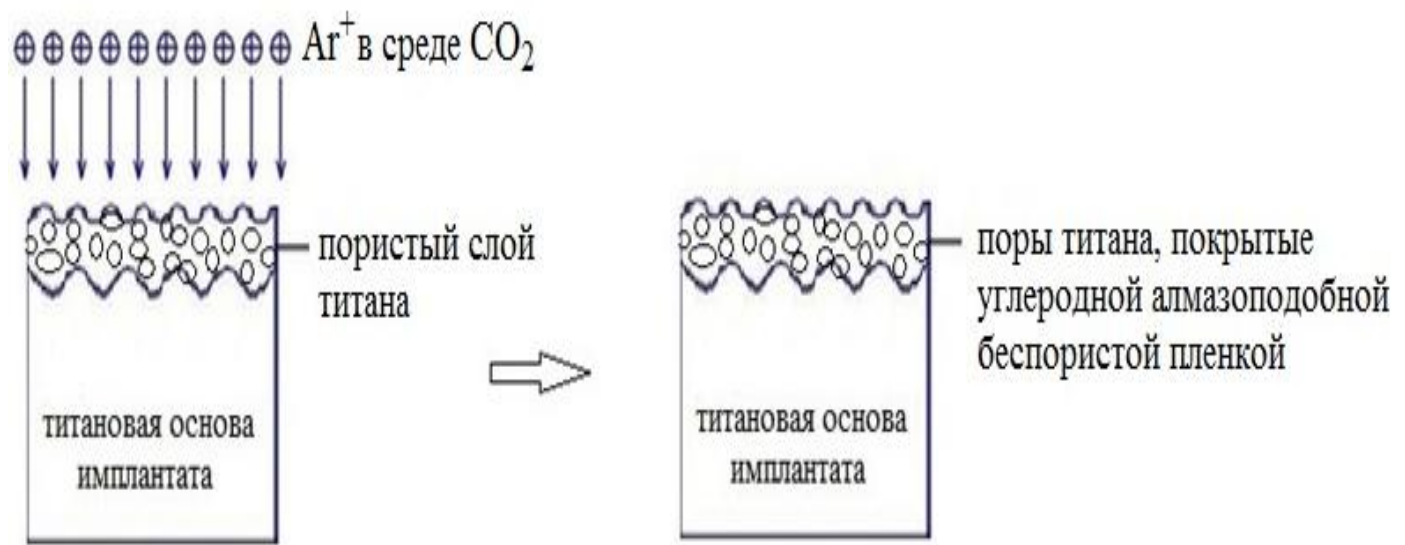

Рис.1. Схема синтеза углеродной алмазоподобной беспористой пленки

Выводы: разработана методика изготовления внутрикостных стоматологических имплантатов $\mathrm{c}$ повышенными остеоинтеграционными свойствами. 


\section{Литература:}

1. Перинская Е.Д., Лясникова А.В. Разработка ионно-лучевой модификации композиционных покрытий с наноструктурными элементами. Сборник трудов XXVI MHК: Участники школы молодых ученых и программы У.М.Н.И.К. в 2ч. Часть 1/ под. общ. ред. А.А. Большакова. Саратов: СГТУ, 2013. - 84-89 c.

2. Перинская Е.Д., Перинская И.В., Перинский В.В., Лясникова А.В. Способ изготовления внутрикостных стоматологических имплантатов с биоактивным покрытием. Заявка на изобретение № 2015101054, дата приоритета 05.05.2015.

3. Перинская Е.Д., Лясникова А.В., Перинская И.В. Инновационная технология изделий биоинженерии с улучшенными эксплуатационными характеристиками // Сборник научных статей 2-й Международной молодежной НПК, в 3-х т., Т.2, Курск: ЮЗГУ, 2015. - 303-304 с. 